日臨外医会誌 $55(4), 822-827,1994$

原著

開心術に扣ける上行大動脈遮断の心筋代謝に及ぼす影響

一乳酸・ピルビン酸代謝を中心として一

東海大学第 1 外科（主任：正津 晃教授）

$\begin{array}{llllrrrr}\text { 藤 } & \text { 邑 } & \text { 尚 } \text { 史 } & \text { 加 } & \text { 賀 } & \text { 基知三 } & \text { 小田桐 重 遠 } \\ \text { 小 } & \text { 出 } & \text { 司郎策 } & \text { 正 } & \text { 津 } & \text { 晃 } & & \end{array}$

体外偱環下に心停止保護液・局所心筋冷却を用いた開心術症例を，上行大動脈遮断時

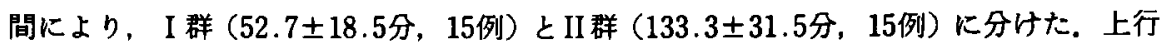
大動脈遮断前・解除直後・15分後・45分後に動脈血・冠静脈血を同時採血し，乳酸・ビ ルビン酸を測定した，冠動静脈血乳酸較差からみると，上行大動脈遮断解除直後は I 群 とII群の心笳の嫌気性代謝は同程度であるが，解除15分後・45分後にはI 群に比しII 群 で嫌気性代謝が持続している，冠動静脈血ビルビン酸較差を指標とすると，上行大動脈 遮断解除直後・解除15分後に, I 群に比べII 群で心筋の嫌気性代謝が明らかであるか， 45分後には両群間に有意差はない，動脈血・冠静脈血の乳酸・ビルビン酸を指標とする 心筋代謝測定は, 上行大動脈遮断時間の限界, 各種心停止法の比較に有用と考之る.

索引用語：開心術に扰ける心筋代謝，心筋保護法

はじめに

体外䛻環下開心術に拈ける心停止法（上行大動脈遮 断, 冷却心停止保護液注入, 局所心筋冷却) は, 施設 により若干の内容の羑異はあるが，臨床上ほぼ確立し た手技となっている。しかしこれの心筋代謝に及ぼす 影響を臨床例について調べた報告は少なく，またこの 場合の心筋虚血の生化学的指漂として何がよいかも未 解決である。われわれは開心術症例の上行大動脈遮断 前・遮断解除後の動脈血・冠静脈血を同時採血し，心 筋の好気性・嫌気性代謝に直接関与する乳酸・ビルビ ン酸を指標として，心停止法の心荕代謝に及ぽす影響 を検討した。

\section{対象と方法}

1992年 4 月から10月の間に手術した開心術30例を対 象とした（表 1)．上行大動脈遮断時間16分～75分（平 均 $52.7 \pm 18.5$ 分）を I 群（短時間遮断群，15例)，105 分 197分（平均 $133.3 \pm 31.5$ 分）をII 群（長時間遮断 群，15例）とした，I 群とII群は，p<0.01にて有意差 を認めた。

術式を表1に示す．I 群は冠動脈バイパス（1３ 本） 5 例，大動脈弁置換 2 例，僧帽弁置換 - 交連切開

1993年11月 1 日受付 1994年 2 月 4 日採用
表 12 群间の患者背最因子

\begin{tabular}{|c|c|c|}
\hline & I 群 & II 群 \\
\hline 上行大動脈遮断時間（分） & $52.7 \pm 18.5$ & $133.3 \pm 31.5$ \\
\hline 体外循環時間（分） & $78.6 \pm 24.3$ & $164.9 \pm 31.3$ \\
\hline 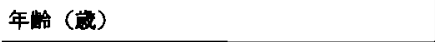 & $3 \sim 71$ & $38 \sim 73$ \\
\hline 大動脈冠動脈ハイバス術 & 5 & 7 \\
\hline 大動质弁酉换術 & 2 & 2 \\
\hline 珰帽升贯換街 & 1 & 2 \\
\hline 直視下僧憛并交重切成術 & 1 & $\mathbf{0}$ \\
\hline 二并管奥術 & 0 & 2 \\
\hline Bentall 手術 & 0 & 1 \\
\hline 心房中雨欠損孔成锤㭪 & 6 & 0 \\
\hline 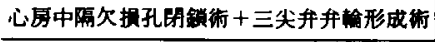 & 0 & 1 \\
\hline 計 & 15例 & 15 例 \\
\hline
\end{tabular}

各 1 例，心房中隔欠損孔閉鎖 6 例である.II群は冠動 脈:イイハス（3－4本）7例，大動脈弁置換 2 例，僧 帽弁置換 2 例， 2 弁置換 2 例, Bentall 手術 1 例, 心房 中隔欠損孔閉鎖兼三尖弁輪形成 1 例である。いずれす 待期的手術例で臨床的重应度に大差はなく, 術後経過 はいずれも順調であった。

体外循環は膜型人工肺を用い，心房中隔欠損症では $32^{\circ} \mathrm{C}$, その他は $26^{\circ} \mathrm{C}$ の中等度低体温, 無血充塓とした。 充填液 (成人) は乳酸リンゲル液 $1,000 \mathrm{ml}, 20 \% \mathrm{D}$-マン ニトール200ml, $5 \%$ ダルコース $2.500 \mathrm{ml}$, 一パリンナ 
表 2 東海大式心你止保蕰洨

\begin{tabular}{lc}
\hline フィジォール3 号『* & $500 \mathrm{ml}$ \\
塩化カリゥム & $3.5 \mathrm{ml}(7 \mathrm{mEq} / \mathrm{l})$ \\
ヘシリン & $1 \mathrm{ml}(1,000$ 単位 $)$ \\
塩酸ジルキアセム & $1 \mathrm{ml}(10 \mathrm{mg})$ \\
\hline
\end{tabular}

- Na $35 \mathrm{mEq} / 1, \mathrm{~K} 20 \mathrm{mEq} / 1, \mathrm{Mg} 3 \mathrm{mEq} / 1$,

Cl $38 \mathrm{mEq} / \mathrm{l}$, Lac. $20 \mathrm{mEq} / \mathrm{l}$, クルコース $100 \mathrm{~g} / \mathrm{l}$

トリゥ $45 \mathrm{ml}(5,000$ 単位 $)$ の混合液を用いた。停止 保護夜は $4{ }^{\circ} \mathrm{C}$ に冷却した東海大式心停止保護液(表 2) を用い, 上行大動脈遮断後直ちに $300 \mathrm{ml}$ (成人量)を大 動脈起始部に注入，ice slashによる局所心筋冷却を併 用した，追加投与（大動脈切開の場合は左・右冠動脈 開口部より）は15２0分毎に $200 \mathrm{ml}$ を注入した。

採血は，(1)体外循環下上行大動脈遮断直前，(2)遮断 解除直後，(3)遮断解除15分後，(4)遮断解除 45 分後（体 外循環続行中）に，動脈血，冠静脈血（冠静脈洞に㨉 入したカテーテルより)を同時採血し，乳酸(比色法), ピルビン酸（比色法）を測定した。これらの測定值は 体外循環回路充填液による希釈を考虑し，患者の循環 血液量 $(\mathrm{CBV}$ ，体重の $1 / 13$ として計算) と回路容量 $(\mathrm{V})$ から,

$$
\text { 希积率 }=\mathrm{CBV}+\mathrm{V} / \mathrm{CVB}
$$

により補正した。

測定値は，平均値土標準偏差で記し，I 群と II 群の 間の有意差は, non-paired Wilcoxon's test によった。

$$
\text { 結果 }
$$

\section{1. 乳酸}

開心術における, 上行大動脈遮断前後の動脈血乳酸 (La)，冠静脈血乳酸（Lv）の変動を, 図 1 (I 群)・ 図 2（II群）に示す。大動脈遮断前はI 群・II群とも に，Laより Lvが同程度に低い。これは心筋がェネル ギー源として乳酸を撕取しており，好気性代謝の状態 にあることを示している．体外循環時間の延長ととも に乳酸は上昇するか，上行大動脈遮断解除直後には， I 群・II 群とむ Laより Lvが高く，冠動静脈血乳酸較 差 (La.Lv)は逆転する。この時点で心筋上り乳酸が遊 出しており，嫌気性代謝の状態にあることを示してい る.

大動脈遮断解除15分後・45分後において，I群（図 1)では La と Lv はほぼ等しく，心筇は未だ乳酸を摂 取できないか，遮断解除直啳の状態より嫌気性代謝は 改善している。しかしII群（図 2）においては，この 時間に依然として冠動静脈血乳酸較差の逆転が続いて

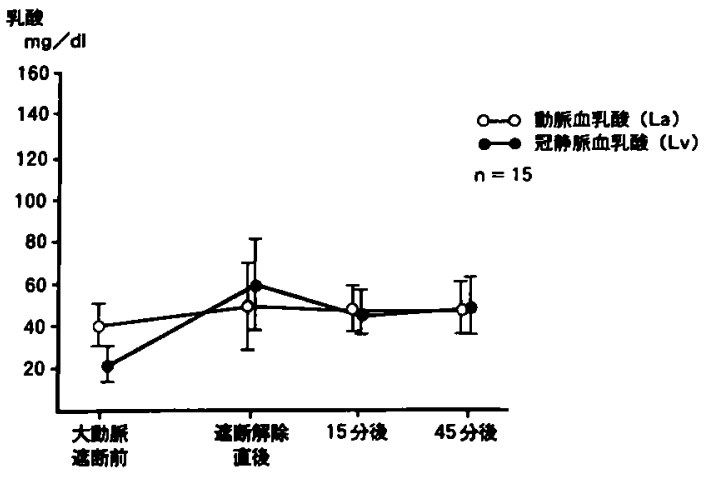

图 1 開心術 I 群（上行大動脈遮断時間： $52.7 \pm 18.5$ 分）における勤脈血・冠静脈血乳酸の变動

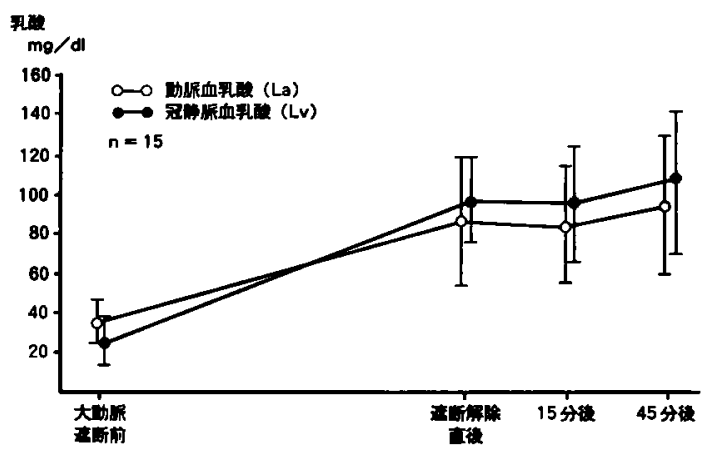

図 2 開心術 II 群（上行大動脈遮断時間：133.3土 31.5分）における動脈血・冠静脈血乳酸の变動

おり，心筋の嫌気性代謝はなお続いているとみなされ る.

以上の所見を更に明確にするために，I 群・II 群の 冠動静脈血乳酸較差を図 3 にまとめた。上行大動脈遮 断前は I 群 $13.5 \pm 8.9 \mathrm{mg} / \mathrm{dl}$, II 群 $9.7 \pm 6.0 \mathrm{mg} / \mathrm{dl}$, 遮 断解除直後は I 群 $-9.5 \pm 11.2 \mathrm{mg} / \mathrm{dl}$, II 群-11.1土 $13.7 \mathrm{mg} / \mathrm{dl}$ で，いずれも両群間に有意差はない，しか し遮断解除 15 分後にはI群 $3.0 \pm 3.4 \mathrm{mg} / \mathrm{dl}$, II 群一 $10.6 \pm 11.6 \mathrm{mg} / \mathrm{dl} て ゙, \mathrm{p}<0.01$ にて両群間に有意差を， 45 分後には I 群 $-2.1 \pm 5.0 \mathrm{mg} / \mathrm{dl}$, II 群 $-13.9 \pm 14.3$ $\mathrm{mg} / \mathrm{dl}$ で, $\mathrm{p}<0.05$ にて両群間に有意差を認めた. II 群 では遮断解除45分に至ってもなお心筇の嫌気性代謝が 続いていることを示している.

体外循環時間の延長に伴って，血中乳酸は次第に上 昇する，この影響をなるべく除くため，以上の成績を 心筋乳酸摄取率 $(\mathrm{La}-\mathrm{Lv} / \mathrm{La})$ としてみたのが図 4 であ る.これにおいても，上行大動脈遮断前は，I 群0.37士 0.22 , II 群 $0.29 \pm 0.22$, 遮断解除直後は I 群 $-0.25 \pm$ 


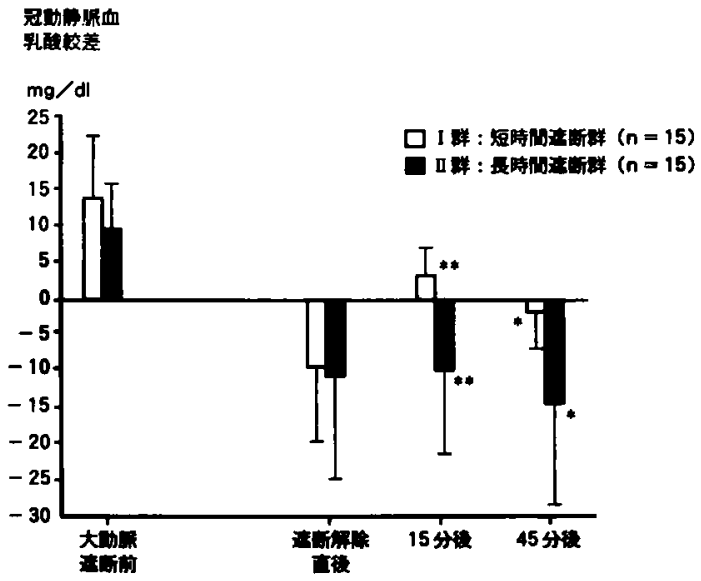

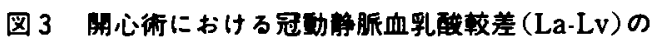
变動

**p<0.01，" $\mathrm{p}<0.05$. I 群と II群間には，大動脈遮 断解除15分後，45分後に有意差を認める。

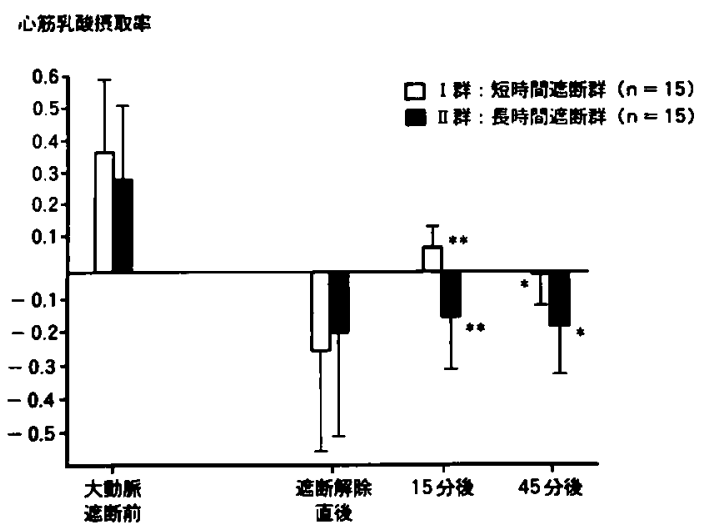

図4開心術における心筋乳酸攝取率 (La-Lv/La)の 变功

** $\mathrm{p}<0.01, * \mathrm{p}<0.05$. I 群と II 群の間には, 大動脈 遮断15分後，45分後に有意差を認める.

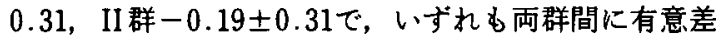
はない。しかし遮断解除15分後にはI群0.06士0.07， II 群 $-0.15 \pm 0.16 て ゙ ， \mathrm{p}<0.01$ にて両群間に有意差を， 45分後にはI 群 $-0.03 \pm 0.10$, II 群 $-0.17 \pm 0.15 て ゙ ，$ $\mathrm{p}<0.05$ にて両群間に有意差を認めた。

\section{2. ピルビン酸}

動脈血ビルビン酸 $(\mathrm{Pa})$ ，冠静脈血ビルビン酸 $(\mathrm{Pv})$ の変動を図 5 (I 群)・図 6 (II 群) に示す。上行大動 脈遮断前には，I 群・II群とも $\mathrm{Pa} ， \mathrm{Pv}$ は近似してい る。体外循環時間の延長とともにビルビン酸も上昇す

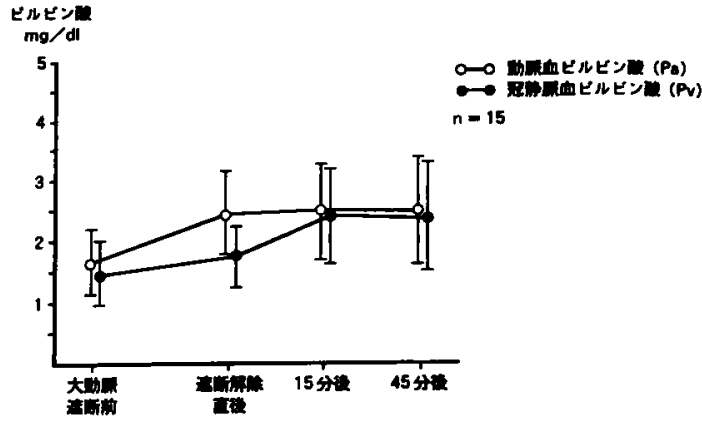

図 5 開心術 I 群（上行大動脈遮断時間：52.7士18.5 分）における動脈血・冠静脈血ピルビン酸の变動

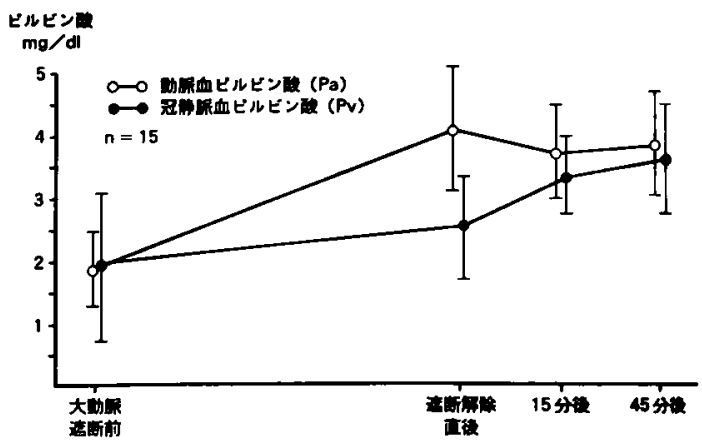

图 6 開心術II群（上行大動脈遮断時間：133.3土 31.5分）におけろ動脈血・冠静脈血ピルビン酸の变 轩

るが，大動脈遮断解除直後には，I 群・II 群とも $\mathrm{Pa}$ と Pvの差は大きくなり，解除15分後，45分後にその差は 次第に樎小傾向を示している。

以上の所見を冠動静脈血ピルビン酸較差 (Pa-Pv) と して图 7 にまとめた. 上行大動脈遮断前は，I 群0.34士 0.38 , II 群 $-0.09 \pm 0.87 \mathrm{mg} / \mathrm{dl}$ で有意差はない。遮断 解除直後は, I 群 $0.71 \pm 0.57 \mathrm{mg} / \mathrm{dl}$, II 群 $1.45 \pm 0.55$ $\mathrm{mg} / \mathrm{dl}$ で, $\mathrm{p}<0.01$ にて両群間に有意差を，遮断解除15 分後には, I 群 $0.11 \pm 0.66 \mathrm{mg} / \mathrm{dl}$, II 群 $0.41 \pm 0.32 \mathrm{mg} /$ $\mathrm{dl}$ で $\mathrm{p}<0.05$ にて両群間に有意差を認めた。しかし45 分後には I 群 $0.11 \pm 0.47 \mathrm{mg} / \mathrm{dl}$, II 群 $0.21 \pm 0.55 \mathrm{mg} /$ dl で，両群間に有意差はなかった。

3. dexcess lactate $(\Delta \mathrm{XL})$

Huckabee ${ }^{11}$ に従い,

$$
\Delta \mathrm{XL}=(\mathrm{Lv}-\mathrm{La})-(\mathrm{Pv}-\mathrm{Pa})
$$

( $\mathrm{La} / \mathrm{Pa})$ に上り $\Delta \mathrm{XL}$ を計算した（图 8 )。心筋虚血 が進むほど，その值は大きくなるとされている。

$\Delta \mathrm{XL}$ は上行大動脈遮断前は, I 群 $-6.6 \pm 5.1$, II 


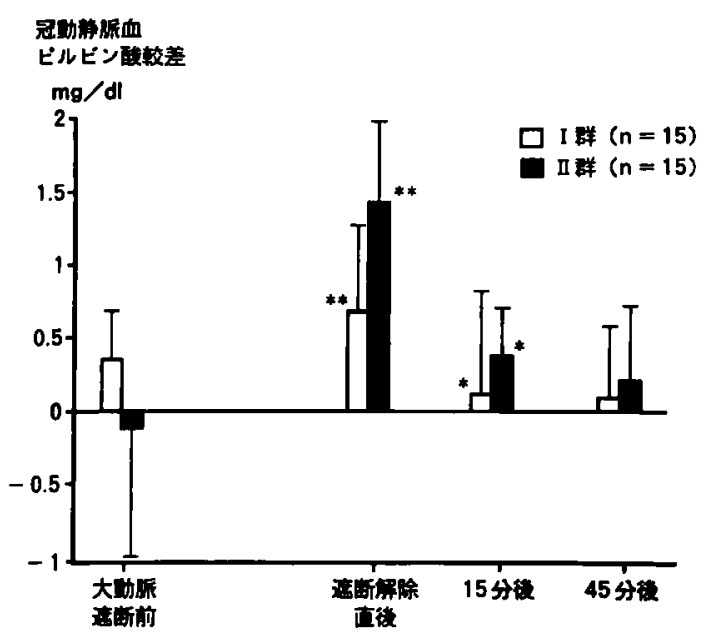

図7開心術における冠動觧脈血ピルビン酤较差 (Pa-Pv) の变动

“p <0.01，“p<0.05. I 群 (短時間遮断群) と II 群 （長時間遮断群）との間には，大動脈遮断解除直後， 15分後に有意差を認める。

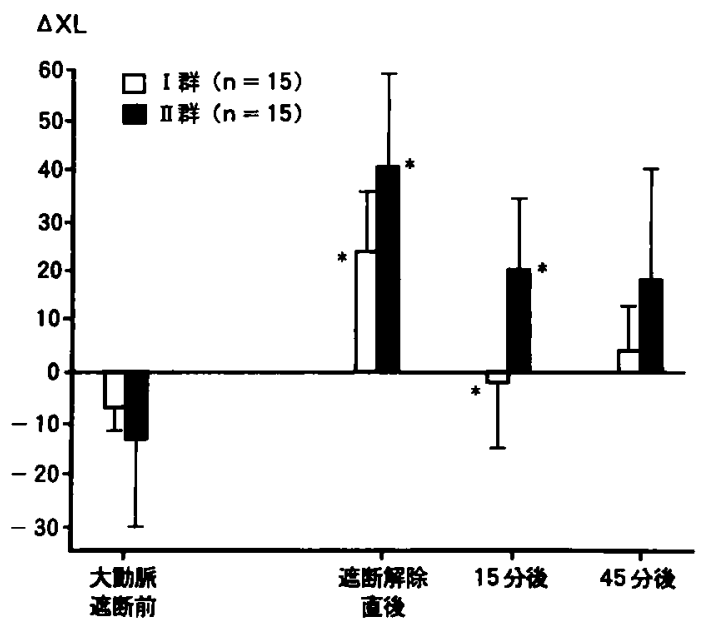

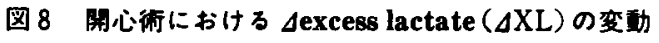
$\Delta \mathrm{XL}=(\mathrm{Lv}-\mathrm{La})-(\mathrm{Pv}-\mathrm{Pa})(\mathrm{La} / \mathrm{Pa})$ "p<0.01. I 群 (短時間遮断群) と II 群 (長時間遮断 群）の間には，大動脈遮断解除直後，15分後に有意 差を認める。

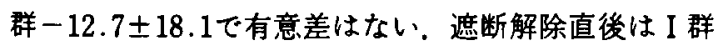
$24.0 \pm 12.3$, II 群40.9土17.7, 解除15分後は I 群一

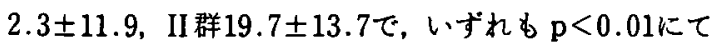
両群間に有意差を認めた。解除 45 分後には I 群 $3.8 \pm$ 8.9, II 群18.3土21.9で, II 群が高かったか，両群間に 統計上の有意差はなかった。
体外循環下開心術の際, 動脈血についてて生化学的変 化を調べた論文2) -51は多いか;，上行大動脈遮断・心筋保

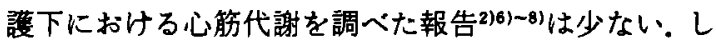
かもその多くは間欠的大動脈遮断2667), 誘発心室細 動"，あるいは選択的冠灌流下216)開心術が行われ，上 行大動脈遮断時間が比較的短かった時代のるのであ り, 現在の心停止保護液注入 - 局所心筋冷却併用，乙 ばしぱ 2 時間を越える大動脈遮断の際における心筋代 謝を，改めて検討することは重要と考える。また最近， 心停止保護液の組成の変更, 逆行性心筋保護法, warm blood cardioplegia などが登場しこれらの優劣を検 討するためには，臨床成績の他に心筋代謝に基ついた 比較が必要であり，またその際には何を生化学的指標 とすべきかが問題となる。

一般に正常心筋のエネルギー源の70\%は遊離脂肪酸 であり ${ }^{9}$, 特に空腹時に使用される.グルコース, 乳酸 むェネルギー源となる。筋は他の組織と異なり，好 気性条件では乳酸をエネルギー源として利用しえるこ とが特徵であり，ビルビン酸を経てクエン酸サイクル に入り，完全に酸化される，すなわち，

乳酸 $+\mathrm{NAD}^{+} \stackrel{\mathrm{LDH}}{\rightleftarrows}$ ピルビン酸 $+\mathrm{NADH}+\mathrm{H}^{2}$ は右に向 か5.

しかし虚血心筋では遊離脂肪酸に代わってグルー スがェネルギー源の主役となり、これはピルビン酸を 経て乳酸になる。すなわち上述の式は左に向から.従っ て心筋における乳酸の利用減少ないし心筋上りの遊出 は，心能虚血の上い指標になるとされている(11011!。

图 3 の冠動静脈血乳酸較差は, 以上の理論により説 明できる，上行大動脈遮断前の心筋は乳酸を摄取し， 好気性代謝の状態にある。遮断解除直後は，I群(短時 間遮断) ・II 群 (長時間遮断) とも同程度の乳酸較差逆 転 (嫌気性代謝) を示し, 遮断時間が 1 時間以内でる 2 時間に及んでも，現在の心筋保護法のもとでは心筋 の嫌気性代謝の程度に大差はないと考えられる。しか し遮断解除15分後・45分後には，II群はII群に比べ明 らかに嫌気性代謝からの回復が晴れている。本研究で は45分後の時点（なお体外循環続行中）までしか追跡 できなかったが，その後の臨床経過は両群間に大差は ないので, II 群の冠動静脈血乳酸較差逆転は, その後 改善に向かっていると推測される。

以上の結果は心筋乳酸摄取率（図4）としてみても 同様であり，やはり上行大動脈遮断解除 15 分後・45分 
後の時点で，I群に比べII群では心筇の嫌気性代謝が 残存している。

冠動静脈血ピルピン酸較差（図７）は，大動脈遮断 解除直後に，I群に比べII群で明らかに増大し，この 状態は解除15分後まで続いている。これらの時点で, 前述の乳酸・ビルビン酸の式は左に向から，すなわち 嫌気性代謝の状態にあることを示している，しかし解 除45分には両群間に有意差はなくなっている.

以上のよらにI群に比へII群の心筋嫌気性代謝は, 乳酸を指標にとれば上行大動脈遮断解除15分後と45分 後に，ビルビン酸を指標にとれば遮断解除直後と15分 後に認められることになる。

低酸素状態の心㬳では乳酸の利用減少ないし遊出が 起こるか，乳酸の成生を促す因子は必ずしも組織の低 酸素症のみとは限らない：そこで心筋の酸素不足状態 を理論的により正しく反映するすのとして， Huckabee" し，心筋の低酸素状態が進しほど，この指標は大にな るとした．しかし実際問題として，ビルビン酸の測定 值は乳酸に比し極めて小さい値であるため，測定誤差 をも考虑に入れると、 $\Delta \mathrm{XL}$ をどの程度信頼すべきか疑 問視するものもある(1)。ここに述べた成績では，I 群に 比しII 群では上行大動脈遮断解除直後・解除 15 分後に, いずれも有意差をもって高値を示し，45分後にも有意 差はなかったが高值を示した，従って $\Delta \mathrm{XL}$ は乳酸・ピ ルビン酸の変動を総合して，体外循環・心筋保護下に おける上行大動脈遮断の心㬳代謝に及ぼす影響をよく 反映していると思われる。

本研究の開始当初，グルコース，遊離脂肪酸，カリ ウムについても，冠動静脈較差を調べた。しかし血糖 值は体外循環中は回路充填液の影響で異常高値を示し (しばしば $500 \mathrm{mg} / \mathrm{dl}$ を越える)となるため指標としに くい，遊離脂肪酸は高血榶の影響を受け，また心䇨虚 血およびそれからの回復過程でェネルギー源の主役で はないので，心筇虚血の指標とすべきデータは得られ なかった。血清カリウムは術中しばしば補正するので, 測定対象としにくい，乳酸一ピルビン酸系は代謝過程 の中間段階ではないので，他の系の影響を受けること が少なく，また両物質とも払散性がよいので細胞内の 状態が比較的よく冠静脈血に反映し，心筋代謝のよい 指標になる(2)と考える。

結語

1）体外循環下に心停止保護液・局所心筋冷却を用い た開心術症例30例を，上行大動脈遮断時間により，I

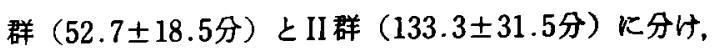
動脈血, 冠静脈血の乳酸・ビルビン酸を指標として, 心筋の好気性・嫌気性代謝の程度を比較した。

2）冠動静脈血乳酸較差・心筀乳酸撰取率からみる と, 上行大動脈遮断解除直後は I 群と II 群の心筋嫌気 性代謝は同程度であるが，解除15分後・45分後にはI 群に比し，II群で心筋の嫌気性代謝が持続していた。

3）冠動静脈血ピルビン酸較差・Dexcess lactateを 指標とすると, 上行大動脈遮断解除直後・解除15分後 に，I 群に比べII 群で心筋の嫌気性代謝が明らかであ るが，45分後には両群間に有意差はなかった。

\section{女 献}

1) Huckabee WE: Relationship of pyruvate and lactate during anaerobic metabolism. V. Coro. nary adequacy. Am J Physiol 200 : 1169-1176, 1961

2) Moffitt EA, Rosevear JW, McGoon DC: Myocardial metabolism in open heart surgery. Arterial levels of metabolites, electrolytes, oxygenation, and acid-base balance. Anesth Analg 48: 633-641, 1969

3) Yokota H, Kawashima Y, Takao T, et al: Carbohydrate and lipid metabolism in open heart surgery. J Thorac Cardiovasc Surg 73 : $543-549,1977$

4) Kuntchen FR, Galletti PM, Hahn C, et al: Alteration of insulin and glucose metabolism during cardiopulmonary bypass under normoth. ermia. J Thorac Cardiovasc Surg 89 : 97-106, 1985

5) 半田宣弘, 許 俊鋭。新井葉子他：体外循環中のヶ トン体分画, 乳酸, ビルビン酸浱度の変化とその臨 床的意義. 日胸外会誌 $40: 1039-1045,1992$

6) Moffitt EA, Rosevear JW, Molnar GD, et al : Myocardial metabolism in open-heart surgery. Correlation with insulin response. J Thorac Cardiovasc Surg 59: 691-706, 1970

7）正津 晃, 山本 弘, 野沢達郎他：体外循環に拈け る anoxic arrest 法ならびに人為心室細動法,とく に心筋代謝を中心として。臨外 25：504-513， 1970

8）石合義弥，小田桐重遠, 嶋津 明他：DBcAMP 加 cardioplegia の心筋保護に対する臨床効果. 臨胸 外 $9: 559-563,1989$

9) Bing RJ : Myocardiol metabolism. Circulation 


$$
12: 635-647,1955
$$

10) Krasnow N, Neil WA, Messer JV, et al ; Myocardial lactate and pyruvate metabolism. J

Clin Invest $41:$ 2075-2085, 1962
11) Scheuer J : Myocardial metabolism in cardiac hypoxia. Amer J Cardiol 19: 385-392, 1967

12）渡辺 務：冠不全時の心筋代謝. 最新医 $25: 67$ $-72,1970$

\title{
EFFECTS ON MYOCARDIAL LACTATE-PYRUVATE METABOLISM OF THE ASCENDING AORTA CROSS-CLAMP DURING OPEN-HEART SURGERY
}

\author{
Takabumi FUJIMURA, Kichizo KAGA, Shigetoh ODAGIRI, Shirosaku KOIDE and Akira SHOHTSU \\ First Department of Surgery, Toaki University School of Medicine
}

We investigated the effect of open heart surgery using cardioplegic soiutions and topical cooling in a cardiopulmonary bypass on myocardial metabolism in subjects divided into two groups based on their aorta cross-clamp time: Group I ( $52.7 \pm 18.5 \mathrm{~min} ; 15$ cases) and Group II (133.3 $\pm 31.5 \mathrm{~min} ; 15$ cases). Blood samples were taken simultaneously from both the arterial and coronary sinus before preforming the aorta cross-clamp, and immediately, 15 and 45 minutes after release of the cross-clamp to evaluate myocardial metabolism using lactate and pyruvate as parameters. From the difference in coronary arteriovenous lactate and the rate of myocardial lactate uptake, the degrees of myocardial anaerobic metabolism in Groups I and II were the same immediately after release of the cross-clamp, but $\mathbf{1 5}$ and $\mathbf{4 5}$ minutes after release, anaerobic metabolism persisted longer in Group II then in Group I. Examination of the difference in coronary arteriovenous pyruvate or excess lactate as parameters, revealed that myocardial anaerobic metabolism was more pronounced in Group II than in Group I immediately and 15 minutes after release of the cross-clamp. However, a significant intergroup difference was not seen $\mathbf{4 5}$ minutes after release of the cross-clamp. These findings indicate that the measurement of myocardial metabolism using arterial and coronary sinus blood lactate and pyruvate as parameters is useful in the comparison of cardioplegic solutions during aorta cross-clamp. 